\title{
How to Put An End to" Media Trial "in Legal News Report
}

\author{
Su Jing \\ School of music and dance, Qujing Normal University, Yunnan 655011 \\ sujing655011@126.com
}

Key words: legal news, media trial, discourse power

\begin{abstract}
: in today's society, media for constant speculation, resulting in a lot of people questioned the impartiality of the judiciary, in fact, trial by media like a double-edged sword, make good use of do for people to justice, with good will to the society bring endless disasters. For such embarrassing Bureau, the author from four aspects to elaborate how to put an end to "trial by media".
\end{abstract}

\section{Introduction}

The concept of "media trial" from the west, originally called "newspaper trial". It refers to the news media in the process of litigation, to influence judicial results and published reports and comments. Needless to say, in the face of the case, press the "rational" reports can play a positive role of supervision of justice. But it is strange is that some reporters does not seem optimistic about this so-called "rational". Some judicial focus in the ratings or personal purpose driven by speculation after the formation of a strong atmosphere of public opinion, the justice department under the social pressure but also to "press public opinion" as the nature of the cases. Such as in the impact of national Deng Yujiao event, Yao the case of child abuse by the judicial department as Yan Yanhong teachers do not constitute a criminal case, these cases strongly stimulate people's nerves, many people questioned the Justice Department, even the network is still Cursed those who suspect defense law. As everyone knows, our country law method: Law expressly not crime, law does not expressly punished. In the news media supervision and judicial, many journalists is often with social moral judge, public opinion to trial suspects. Needless to say, "trial by media" not only affects the judicial justice, or even lead to greater social contradictions. Public opinion like a double-edged sword, make good use of the sword, do for justice for the people, for the legal reveal commanding me? I think we should paint the following:

\section{Repositioning the social role of legal news}

With the development of the legal Chinese media reports and comments of the legal news report not only stay in previous reports of law, supervision of the judicial level, the media are using some new concept of full coverage of legal events. These events were reported by law, to actively participate in the review, hot, very good no doubt to promote judicial justice in our country. As of 1997, killed by driving the original Zhengzhou Municipal Public Security Bureau Zhang Jinzhu drunk, hit each one. Dahe > first reported the case, the provincial leadership requirements severely punished, publicly reported, will not be tolerated. Zhengzhou City Intermediate People's court sentenced Zhang Jinzhu to death. Zhang Jinzhu said that he was planted in the reporter's hand. In fact, if not because of media reports, the excessive attention of the society, Zhang Jinzhu is not sentenced to death. In these cases, we ever more See clearly the social factors behind the judicial behavior implied, the effect is so large that the relationship is so subtle. There are more cases, due to various 
effects, by press some lawyers, legal workers under the pressure of public opinion, judicial trial and media in the game in the to tilt to the public. Montesquieu pointed out in "the spirit of law >:" if the judiciary is not independent and legislative and administrative power, freedom did not exist. The law of our country stipulates: "the people's court in accordance with the law to exercise judicial power independently, not by administrative organs, social organizations and individuals to interfere." therefore, journalists should redefine the legal incidents reported the social role.

Some legal issues, especially the legal disputes more concentrated reflection of social contradiction, it is easy to traction line of sight and public attention as the subject of public opinion. Because the degree of legal protection behind the incident reflects the degree of civilization of a country and the rights and interests of the people. In the face of these public and individual interests are closely related the fact that the media should play the guiding role of public opinion. Because of individual differences, every audience will have different views on controversial events, how to face rationally and law, science and law, collision facts and law, I am afraid neutral role journalists is particularly important not artificial. Emotional reported in the report; not completely reflect the public opinion to the government, just and impartial. Without trial, reported that for the case of qualitative conviction is Wrong, in critical reviews in lack of goodwill, groundless accusations, disorderly buckle hat approach not only produces negative consequences can not be ignored, the fair and honest law enforcement also constitute an obstacle.

Reports of re positioning of law, is to establish a neutral position in the party and the audience. These views should not only represent the voice of the people, in the public opinion from justice to the audience pointed out mistakes; to take the initiative and administrative, legislative, judicial and other state authority for communication, dialogue and consultation, so as to realize the benign interaction between the people and the country. Subtly spreading neutral thought in some of the cases reported in the legal reason deeply. Legal news social role change from the past "strict control" for the development of "smart way"; from the past to let people see what to teach people how to see "; from the past to" block ", which guarded the media into" pass ", take the form of congestion and blocked the wrong opinion, to" guide ", in full respect for people Freedom of speech, allowing different views and opinions published simultaneously analysis of legal theory, to popularize legal knowledge. Give full play to the role of the function of "agenda setting" and "opinion leaders". In many important cases reported, with the eyes of a legal person positive on an unbiased view.

\section{The head start to seize the right to speak}

Fired Hunan raise a Babel of criticism of the corruption case of Jiang Yanping came to an end. During the trial of the case, many media reports given great attention, overwhelming, or generous pages. Against the defendant by public funds, Yuhenantian, or talked about the defendant's affair, private life. Coincidentally, Zhejiang Wenling child abuse teachers Yan Yanhong the Department of justice that does not constitute a crime, but also strongly stimulate people's nerves, a lot of people in the denunciation of Yan Yanhong at the same time, the Department of justice in the handling of suspected cases, request to be punished do personnel, even on the Internet on the basis of the existing legal provisions of the abuse of child abuse fine defense legal experts in the development of law., due to lack of foresight, some new things cannot be found in the past according to law, and without law is not a crime, judicial judgment undoubtedly Will allow the public to doubt the mood. For such cases, the media involved in the judicial proceedings to the judge brought the invisible pressure, resulting in the conviction and sentencing process to meet the audience and thus undermine the independence of the judiciary. 
Judge should be based on facts, the law as the criterion. To determine whether a person is guilty, the trial and sentencing, qualitative to the law, according to the verdict is the facts of the crime, the circumstances of the crime and social harm, must be verified, and to form a complete chain of evidence and proof of the judiciary in Wenling against the system. The pressure, according to the release of child abuse fine, this is not only to the media and the public a reminder: judicial public opinion can not be kidnapped, the supremacy of constitutional law. The media supervised the right to justice does not mean the media. The media significance lies in some people concerned about the case caused more extensive reveal to the public. The attention of the society, so that the majority of people's right to know maximize, if the defendant is not guilty of death, even if Jieyue can kill people, nor the judge sentenced the defendant to death Punishment.

Rumors stop wise, lies open. In the Internet era, the legal hot news after the incident, to cover is not cover, want to deceive is not, want to block is not feasible, practitioners only publish authoritative information in the first time, timely grasp the right to speak, to strengthen the "first effect", neutral to report the legal incident to seize the high ground of public opinion. As Bai Yansong said, there is a propagation rule, any sound when the first time occupied the minds of the people, whether it is right or wrong, behind you want to use the new sound to cover it is a very difficult thing, you have become very passive. So, as a law reporter, should stand in the legal level of speech; but to stand on talking guide height of public opinion.

\section{The use of "balance principle" in the legal news report}

If the judge asked the judge to a balance, justice and legal parties, so journalists should balance the same legal events like justice, neither inclined to the plaintiff, the prosecution authorities, nor inclined to the defendant. A case of unfair trial result maybe only a few people on the legal authority of the suspect. An unjust Report triggered doubts, I am afraid to use tens of thousands of or more to calculate. So we can say, objective and impartial legal news reports than case judge is more important, because we are faced with a wide audience. The reporter to learn how to use the "balance principle" in the report. "The principle of balance" is to deal with the parties, social effect, balance the relationship between the Department of justice, in a fair, impartial, neutral attitude towards the case. Both consider the parties' positions, and To emphasize the importance of social stability, but also to stand in the legal aspects of thinking. Involuntary imagination, without resentment, not exaggerated and distorted the facts, don't feel free to comment, ignorance of the law more cannot assume discussion law.

How to achieve "the application of the principle of balance"?: first is to control the relevant reports caliber, to guide the audience "what to think". Not long ago, the son of Li Shuangjiang Li Tianyi and other celebrities five suspected woman raped a case after reporting, has sparked heated debate, because of Li Tian a famous father and two rich generation this case report identity, let reporters more material for speculation. Some media questioned Li Tianyi over age, even out years ago Li Shuangjiang couples do show video evidence of its adult. According to the criminal law of the people's Republic of China $>$ 236th, seventeenth provisions: the rape of women, 3 years more than 10 years of fixed-term imprisonment. But if there is a gang, should increase the punishment. The full 16 years of age who commits a crime shall bear criminal responsibility; has reached the age of 14 and 18 years of age who commits a crime shall be given a lighter or mitigated Punishment. According to the police investigation, the 17 year old Li Tianyi should be given a lighter or mitigated punishment, so the sentence should be in 3 to 10 years. The law of our country has been on juvenile offenders have a series of protection policy, theory of Li Tianyi finally may obtain the sentence for 3-10 years. In this case, can not be Li Tianyi denied the special identity is the reporter 
from the hype gimmick, people shouting to see the side of him just to punish evil, but in China on the protection of minors is a special law, to protect all minors. As a reporter, in these legal report reporters should carefully, reduction the truth can not be used. People thought to report the facts, from the legal level to guide the audience, what to think, how to think.

Secondly to influence the audience "how to think". In 2003, Li Guifang was caught stealing, because investigators "not as" daughter Li Siyi was starved to death at home in. Sichuan media reporter failed to issue the manuscript in the newspaper under pressure, then in the network issued, immediately aroused widespread concern. The people's court hearing the case, the police are involved the prosecution alleged dereliction of duty. In this case under the supervision of the public to mingaoguan can win. If the reporters did not stand on the legal position, just stand on the moral court trial, Li Guifang will think the thief should be punished, while ignoring the legal level is actually the thief, but not legal procedures because she is a violation of the thief. So, the reporter should actively grasp the right words in legal incident report, and actively guide the audience "how to think". The last is to make the audience " Think ". Legal knowledge due to its professional and not the audience know. Therefore, many audiences are influenced by self generated knowledge limitations, resulting in a legal useless theory and the universal theory of law thoughts, that court everywhere is the place of darkness, or think anything as long as the recourse to the law will have a happy ending. These ideas are one-sided, not correct. As a media person should stand on the position of the legal person, guide the audience think, think so.

\section{Improve the legal quality, strict self-discipline of Legal Report}

The news reporter reports formed in the atmosphere of public opinion, influence on a case is very great, it is embodied in: firstly, pretrial affects the independence of the judiciary. The judge in a specific case should be independent of applicable legal rules, and not by any external influence and pressure. Secondly, the obstruction of Justice in the moment of judgment. The judge, by other views or by any external power control or influence, it is difficult to judge the fair judgment. As Kant said: "justice is the moral imperative" from the inside. In addition, the trial will also undermine judicial authority. Some cases of the first instance is a point of view that appeal to the second trial, and sentenced because of the pressure of public opinion to judge the public trust this seemingly "public opinion" of victory, they distort justice, violated the judicial authority.

Can not imagine, as media people do not understand the law how to guide the audience? To improve the legal literacy of media people, the most effective way is to guide the news reporter system and learning the law, good good news coverage and public opinion in the provisions of the Constitution and the laws and regulations in all areas. In practice, some reporters in the report of the legal consciousness indifferent, punished by law. Therefore, learning the law is the most effective protection means. Analysis of media can not regularly invite newspaper lawyer, on stage or annual case, key case and new promulgation and implementation of the laws and regulations. I think we should set the corresponding legal courses in journalism and communication professional undergraduate and graduate courses, early cultivation of legal quality of future news talent.

In reports should also abide by the media reports judicial autonomy principle. Such as: before the judgement in the case without conviction, qualitative reports; the parties legitimate exercise of the rights of words and deeds don't tend to do commentary; in cases involving minors, women, the rights and interests of the elderly and disabled, be of particular concern; unfavorable reports involving state secrets, commercial secrets, personal privacy case; do not do the action party spokesperson; general comment after the verdict; critical comments should be avoided for the judge's personal character knowledge. 
Media reports judicial self-discipline principle is a glass container, it asked the reporter to myself into the reality of courage, let audience and the law common to supervise his. In the report, not only considering the ratings and hype events, local amplification, such as on real sister, cousin and other social evils excessive speculation, will let the audience lose reason, to the imaginary society unfair, legal aweless.

\section{References}

[1] Meng Lijuan. New development of media trial: network media trial analysis [J] Anhui Literature (second half); 2010 (05): 23-33.

[2] Chen Shuo. Media trial of the network age [J]. Jiang Huai Forum; 2010 (05): 14-16.

[3] Wang Jun Li Wangying. In the era of Internet information supervision by public opinion and judicial -- Taking the case of Hangzhou drag racing accident as an example [J]; the spread of Modern Journal of Communication University of China. 2009, (04): 22-24.

[4] Liu Juan; Tang Zhongke; media trial -- the alienation of media power [J]; news lover; the 18 phase of the 2009 25-28. 